\title{
Sampling methods for clover species in grazed pastures to diagnose mineral deficiencies
}

\author{
Sonya T. OLYKAN*, Richard J. LUCAS and Derrick J. MOOT \\ Dryland Pastures Research, Field Research Centre, Faculty of Agriculture \& Life Sciences, \\ PO Box 85084, Lincoln University, Lincoln 7647, New Zealand \\ *Corresponding author: sonya.olykan@lincoln.ac.nz
}

\begin{abstract}
Diagnosis of clover nutrient status is important for legume-based pasture systems. The protocols for sample collection and setting of nutrient guidelines are ill-defined. This research quantified how nutrient concentrations differed between laminae (leaflets) and petioles (leaf stems) of subterranean (sub) clover (Trifolium subterraneum) and white clover (T. repens) as a first step in developing appropriate sampling procedures to examine the nutrient status of clover species.
\end{abstract}

Field samples of sub and white clovers from three pasture sites in the Wairarapa and Canterbury were separated into lamina and full petiole and chemically analysed for nitrogen $(\mathrm{N})$, phosphorus $(\mathrm{P})$, potassium $(\mathrm{K})$ and sulphur (S). Lamina + petiole K concentrations were lower in sub clover $(2.3 \%)$ than white clover (3.2\%). Across both species, the lamina concentrations of $\mathrm{N}(4.9 \%), \mathrm{P}(0.36 \%)$ and $\mathrm{S}(0.28 \%)$ were higher than in the petiole $(1.8 \%, 0.29 \%$ and $0.12 \%$ respectively) but the reverse was found for K (1.8\% lamina, 3.7\% petiole). As a consequence, increasing the proportion of petiole added with the lamina affected the nutrient concentration of lamina + petiole samples so that $\mathrm{N}, \mathrm{P}$ and $\mathrm{S} \%$ declined but $\mathrm{K} \%$ increased.

In a subset of samples, NIR analysis found the crude protein of lamina + petiole in white clover was $24 \%$ compared with $21 \%$ in sub clover. Clover laminae of both species had $33 \%$ crude protein compared with only $11 \%$ in the petiole.

The diagnosis of clover nutrient status for fertiliser recommendations should be based on lamina-only samples. In contrast, mixed pasture samples for nutritive value analysis should include clover laminae and petioles, plus grass and herb pasture components, to simulate grazing intake by livestock.

The lack of defined sampling protocols may explain some of the difficulties previously reported in herbage nutrient interpretation and reconciling soil test results.

Keywords: Critical values, foliar nutrient concentration, lamina, nitrogen, pasture, petiole, potassium, phosphorus, sampling, subterranean clover, sulphur, white clover

\section{Introduction}

Over the last 20 years, promotion of grazing management to favour subterranean (sub) clover (Trifolium subterraneum) has resulted in increased productivity from summer-dry hill-country sheep and beef farms in New Zealand (Grigg et al. 2008). Sub clover is the dominant legume in areas where the summer-dry period is usually longer than three months and white clover (T. repens) is normally absent (Costello $\&$ Costello 2003; Grigg et al. 2008). In pastures where summer water stress is less severe, sub clover and white clover may co-exist with sub clover dominating on sunny hill slopes and white clover thriving on shady slopes (Gillingham et al. 1998; Olykan et al. 2019).

Management to favour the clover species best suited to climate and soil moisture conditions should also be matched with routine soil and herbage testing to ensure adequate mineral nutrition of clovers. This approach should then result in efficient fertiliser use, increase in nitrogen $(\mathrm{N})$ fixation, and pasture feeding value.

Herbage is sampled for chemical analysis from grazed pastures on farms so that reliable advice may be provided on either the nutritive value (mineral, energy and protein) of the pasture on offer to livestock or to determine the macro and micronutrient status of the pasture's clover component.

Sampling clover, rather than mixed herbage, for accurate assessment of clover nutrient concentrations has been widely recommended, e.g. McNaught (1970), Morton and Smith (2000), but most authors do not state the proportions of clover plant parts in their samples. In fact, few authors have recognised that the nutrient content of the green photosynthetic lamina differs from the pale coloured structural petiole (leaf stem) or clover stem (stolon in white clover or runner in sub clover). A notable exception was an Australian study which reported the $\mathrm{N} \%$ and dry matter (DM) digestibility of sub clover plant parts (Ru \& Fortune 2000). They found that the mean lamina $\mathrm{N} \%$ of late-maturing sub clover cultivars at the vegetative stage was $4.8 \%$ while petioles contained $2.4 \% \mathrm{~N}$. Ru and Fortune (1999) also reported that the ratio of lamina to petiole DM changed through the spring growing season from 80:20 down to 50:50. In New Zealand, McNaught (1958) reported a study on potassium $(\mathrm{K})$ nutrition in sub and 
white clovers where lamina and petiole were analysed separately. Petioles had up to twice the K concentration of laminae in healthy plants. Those differences in $\mathrm{K} \%$ between plant parts were discussed with regard to plant sampling, when the proportion of petiole varied in a clover lamina plus petiole sample. However, the author did not provide a recommendation for sampling clover that would overcome this issue. Over time, those results seem to have been overlooked.

Most crops have specific sampling regimes for nutrient diagnosis, which define plant part and stage of plant development. For example, Reuter and Robinson (1997) in their CSIRO 'Plant Analysis Manual' recommended that the youngest mature leaf should be sampled from many annual crop species such as pulses, beet, canola, and cotton. Similarly, they also stated that the two youngest open leaves on a stem be sampled from clovers. In spite of recognised protocols for other species, pasture sampling has been rather arbitrary and potentially more related to animal intake and convenience than consistency and precision.

Commonly, harvests of carefully conducted pot experiments are designed to measure clover responses to rates of nutrients but few have sampled the youngest open laminae. Rather, plants are cut at a predetermined height (e.g. to leave a stubble of $20 \mathrm{~mm}$ ) so the herbage samples from a range of legumes can differ in the proportions of lamina, petiole and stem material. With mixed herbage samples cut from field experiments or farm paddocks, the legume component may be separated to determine the botanical composition of the pasture on a DM basis. Any dry clover in the sample may then be sent for chemical analysis with the proportions of lamina, petiole and stem being unknown. The implication is that the unknown proportion of clover lamina to petiole plus stem influences the nutrient data. Nutrient results from samples containing only laminae may be more reliable and easier to interpret.

For sub clover, a second issue relates to the current use of white clover mineral nutrient values, which are used as the standard for assessing other pasture clovers. Weir and Cresswell (1994) presented the same critical values for both sub and white clovers but Reuter and Robinson (1997) described separate "marginal deficiency" foliar nutrient concentration ranges which indicated that the two species are different particularly for $\mathrm{N}$, i.e. a range of $4.4-4.7 \% \mathrm{~N}$ for white clover and $3.0-3.2 \%$ for sub clover (Table 1). Cornforth and Sinclair (1984) did not include sub clover in their fertiliser recommendations for New Zealand pastures but the "optimal" nutrient values they describe for white clover are the same as those currently used by commercial laboratories for white clover and, by default, for sub clover.

Pot experiments that compared responses of several
Table 1

Standard critical values for N, P, K and S in white clover and sub clover from literature sources.

\begin{tabular}{|c|c|c|c|c|}
\hline \multicolumn{3}{|c|}{ ‘Marginal deficiency’’ } & \multirow{2}{*}{ 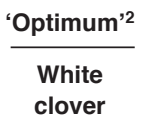 } & \multirow{2}{*}{ 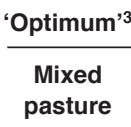 } \\
\hline Nutrient & $\begin{array}{l}\text { White } \\
\text { clover }\end{array}$ & $\begin{array}{l}\text { Sub } \\
\text { clover }\end{array}$ & & \\
\hline $\mathrm{N}(\%)$ & $4.4-4.7$ & $3.0-3.2$ & $4.8-5.5$ & $4.7-5.5$ \\
\hline $\mathrm{P}(\%)$ & $0.30-0.34$ & $0.30-0.40$ & $0.35-0.40$ & $0.35-0.40$ \\
\hline $\mathrm{K}(\%)$ & $1.7-1.9$ & $1.5-2.5$ & $2.0-2.4$ & $2.5-3.0$ \\
\hline $\mathrm{S}(\%)$ & $0.22-0.26$ & $0.18-0.30$ & $0.27-0.32$ & $0.28-0.35$ \\
\hline
\end{tabular}

1 Associated with a reduction in plant growth but no visible signs of deficiency, but requiring nutrient addition. Criteria based on the youngest open leaves collected during active growth prior to flowering for both clover species from a number of published experiments (Reuter \& Robinson 1997).

2 For samples of 'leaf' plus [part] petiole taken from grazing height under conditions conducive to active growth (Cornforth \& Sinclair 1984).

3 From Morton and Roberts (2018), calibrated against pasture production.

legume species, including sub and white clovers, to rates of nutrients such as phosphorus $(\mathrm{P})$ or sulphur (S) have shown significant differences among species (Maxwell et al. 2012, 2013; Moir et al. 2016). These results suggest that specific foliar nutrient critical values are required for sub clover which is an economically important legume in New Zealand dryland farming systems.

The aim of this paper is to examine variation in nutrient contents of clover herbage samples based on their morphological components and from there identify the need for standard protocols for sampling clover from grazed pastures for foliar analyses.

\section{Materials and Methods}

\section{White clover and sub clover}

For this study, the clover sampling process was based on handpicking bunches of mature laminae from the upper pasture canopy - this reflects a realistic and practical approach to field sampling by 'grab' or 'snip' samples rather than searching the lower canopy of the sward for the youngest open leaves as recommended by Reuter and Robinson (1997).

Samples of sub and white clovers were collected from three dryland pasture sites from October 2017 to January 2019 (Table 2). At the time of sampling, the Tokaroa Farm site was a set-stocked clover-grass pasture (Olykan et al. 2019), and the Ashley Dene and Iversen sites were rotationally grazed clover-grass pastures. Sample sorting was based on selecting fully expanded functional lamina, not visibly discoloured by disease, nutrient deficiency, senescence, or affected by pest damage, that also had a full petiole (leaf stem) as indicated by the presence of the stipule. Laminae (leaflets) were manually separated from the petioles. In general about 100 laminae were required to provide sufficient DM for analyses. For each 
Table 2 Location, date of sampling, and chemical analyses undertaken for sub clover and white clover lamina and petiole samples.

\begin{tabular}{llll}
\hline Clover species & Site name (Location) & Date & Analyses \\
\hline Sub \& White & Tokaroa Farm (Wairarapa) & $26 / 10 / 2017$ & Nutrients \\
Sub & Iversen 9/10 (Lincoln, Canterbury) & $24 / 08 / 2018$ & Nutrients \\
Sub \& White & Ashley Dene (Springston, Canterbury) & $29 / 08 / 2018$ & Nutrients \& NIR \\
Sub \& White & Ashley Dene (Springston, Canterbury) & $5 / 10 / 2018$ & Nutrients \& NIR \\
White & Iversen 9/10 (Lincoln, Canterbury) & $11 / 01 / 2019$ & Nutrients \& NIR \\
\hline
\end{tabular}

sample, laminae or petioles were counted, dried at $65^{\circ} \mathrm{C}$, weighed, ground separately, and analysed by Analytical Services, Lincoln University. Nitrogen concentrations were found by combusting a $0.2 \mathrm{~g}$ of sample at $900^{\circ} \mathrm{C}$ in an oxygen atmosphere and analysing the resulting $\mathrm{N}_{2}$ gas with a Vario-Max $\mathrm{CN}$ Elemental Analyser (Elementar Gmbh). Foliar P, K and $\mathrm{S}$ concentrations were measured by adding 2.0 $\mathrm{mL}$ of trace element grade nitric acid $(69 \%)$ and 2.0 $\mathrm{mL}$ of $30 \%$ hydrogen peroxide to $0.2 \mathrm{~g}$ of sample, digesting by microwave (CEM MARS Xpress; $4.6^{\circ} \%$ min to $90^{\circ}$ (held for $5 \mathrm{~min}$ ) followed by $9^{\circ} / \mathrm{min}$ to $180^{\circ}$ then held for $15 \mathrm{~min}$ before cooling) and analysing with an ICP-OES (Varian 720). Foliar nutrient concentrations were compared with the standard critical values shown in Table 1.

A subset of lamina and petiole samples (see Table 2) were analysed using near-infrared (NIR) spectroscopy (FOSS NIRSystems 5000) for metabolisable energy (ME), crude protein, acid detergent fibre (AFD) and neutral detergent fibre (NFD). See Osborne et al. (1993) for NIR theory and methodology.

Based on the data for separate lamina and petiole samples, a range of lamina to petiole ratios were calculated for concentrations of $\mathrm{N}, \mathrm{P}, \mathrm{K}$ and $\mathrm{S}$ so that 100:0 represented lamina only and 50:50 was half lamina and half petiole by dry weight (DW) for sub clover and white clover.

\section{Soils data}

The soils at Tokaroa Farm were classed as Argillic Pallic and are moderately deep (0.6 to $0.9 \mathrm{~m}$ ) with poor drainage (S-MAP 2018). At the Ashley Dene and Iversen sites the soils were predominantly Wakanui silt loam (Cox 1978), classed as a Mottled Immature Pallic. This soil is deep, stoneless and poorly draining (Hewitt 2010). Soil samples (0-75 mm depth) were taken from the three sites at or near the time of foliage sampling. The soil samples were air dried $\left(35-40^{\circ} \mathrm{C}\right)$ overnight, crushed to pass through a 2-mm sieve and analysed for $\mathrm{pH}, \mathrm{P}, \mathrm{K}, \mathrm{Ca}, \mathrm{Mg}$ and $\mathrm{S}$ by Hill Laboratories Ltd using standard methods.

Differences between the sites were a lower $\mathrm{pH}$ of
5.5 and $\mathrm{K}$ of $0.3 \mathrm{me} / 100 \mathrm{~g}$ at Tokaroa Farm (Table $3)$. Across the sites, the amounts of sulphate-S and organic-S were low $(2-5 \mathrm{mg} / \mathrm{kg}$ ) considering a range of 10 to $12 \mathrm{mg} / \mathrm{kg}$ for both forms is considered optimum for pasture production (Edmeades et al. 2005).

\section{Statistical analyses}

Dry weight and nutrient concentration data were analysed with Genstat statistical software (18th edition). The DW and nutrient concentration for white or sub clover (species) lamina or petiole (plant part) samples were analysed by two-way (species $x$ part) ANOVA (location as covariate) and within each clover species by one-way (part) ANOVA (location as covariate). Covariate adjusted means are presented. The ME, protein, AFD and NDF data were analysed by two-way (species $\times$ part) ANOVA. Main factor means separation used a Fishers protected LSD of $5 \%$.

\section{Results}

\section{Foliar nutrient concentrations}

Clover species affected the average lamina and petiole DW and the foliar K concentration (Table 4). White clover had a higher $(\mathrm{P}<0.05) \mathrm{DW}$ of $0.036 \mathrm{~g}$ compared with $0.023 \mathrm{~g}$ for sub clover. The foliar $\mathrm{K}$ of $3.2 \%$ in white clover was higher $(\mathrm{P}<0.05)$ than the $2.3 \%$ in sub clover.

Table 3 Soil chemical characteristics in samples taken from 0-75 $\mathrm{mm}$ at Ashley Dene and Iversen Fields (Canterbury) and Tokaroa Farm (Wairarapa). MAF Quick Test units are shown in brackets.

\begin{tabular}{lccc}
\hline & \multicolumn{3}{c}{ Site } \\
\cline { 2 - 4 } Chemical characteristic & Ashley Dene & Iversen & Tokaroa \\
\hline $\mathrm{pH}$ & 6.3 & 6.1 & 5.5 \\
Olsen P (mg/L) & 22 & 21 & 21 \\
Potassium (me/100 g) & $0.78(14)$ & $0.58(12)$ & $0.3(5)$ \\
Calcium (me/100 g) & $9.9(11)$ & $6.3(8)$ & $6.6(7)$ \\
Magnesium (me/100 g) & $0.91(18)$ & $0.85(19)$ & $1.4(27)$ \\
Sulphate sulphur $(\mathrm{mg} / \mathrm{kg})$ & 2 & 2 & 3 \\
Organic Sulphur $(\mathrm{mg} / \mathrm{kg})$ & 5 & 3 & 5 \\
\hline
\end{tabular}


Table 4

Dry weight and nutrient concentrations of sub and white clover (WC) laminae and petioles collected from the Wairarapa and Canterbury (see Table 2). $\mathrm{SEM}=$ standard error of the mean .

\begin{tabular}{lllllll}
\hline Factor & & DW $(\mathbf{g})$ & $\mathrm{N} \%$ & $\mathrm{P} \%$ & $\mathrm{~K} \%$ & $\mathrm{~S} \%$ \\
\hline Species & Sub & $0.023 \mathrm{~b}^{*}$ & 3.2 & 0.31 & $2.3 \mathrm{~b}$ & 0.19 \\
& WC & $\mathbf{0 . 0 3 6} \mathrm{a}$ & 3.5 & 0.35 & $\mathbf{3 . 2} \mathrm{a}$ & 0.21 \\
\cline { 2 - 7 } & P values & 0.007 & 0.115 & 0.110 & 0.013 & 0.202 \\
\hline Plant part & Lamina & $\mathbf{0 . 0 3 4} \mathrm{a}$ & $\mathbf{4 . 9} \mathrm{a}$ & $\mathbf{0 . 3 6} \mathrm{a}$ & $1.8 \mathrm{~b}$ & $\mathbf{0 . 2 8} \mathrm{a}$ \\
& Petiole & $0.025 \mathrm{~b}$ & $1.8 \mathrm{~b}$ & $0.29 \mathrm{~b}$ & $\mathbf{3 . 7} \mathrm{a}$ & $0.12 \mathrm{~b}$ \\
\cline { 2 - 7 } & P value & 0.043 & $<0.001$ & 0.039 & $<0.001$ & $<0.001$ \\
\cline { 2 - 7 } & SEM & 0.0030 & 0.113 & 0.016 & 0.203 & 0.010
\end{tabular}

* Within each factor bolded means were significantly greater $(\mathrm{P}<0.05)$.

Clover plant part (lamina or petiole) affected the concentrations of N, P, K and S (Table 4). Concentrations of $\mathrm{N}$ and $\mathrm{S}$ were higher $(\mathrm{P}<0.05)$ in the lamina than the petiole by more than a factor of 2 but $\mathrm{K}$ was higher $(\mathrm{P}<0.05)$ in the petiole. $\mathrm{N}$ was $4.9 \%$ in the lamina compared with $1.8 \%$ in the petiole, and $\mathrm{S} \%$ was $0.28 \%$ and $0.12 \%$, respectively. In contrast, $\mathrm{K}$ was $3.7 \%$ in the petiole which was 2 times higher than the $1.8 \%$ in the lamina. The DW and $\mathrm{P} \%$ of lamina was higher $(\mathrm{P}<0.05)$ than in the petiole.

\section{Within clover species, laminae and petioles had} different nutrient concentrations

When the clover species were statistically analysed separately, foliar $\mathrm{N} \%$ and $\mathrm{S} \%$ were affected $(\mathrm{P}<0.001)$ by part (lamina or petiole). Foliar N\% was higher $(\mathrm{P}<0.05)$ in the lamina, at $\sim 5 \%$, compared with $\sim 1.8 \%$ in the petiole (Figure 1A). S was $0.30 \%$ and $0.25 \%$ in white and sub laminae, respectively, with $0.12 \% \mathrm{~S}$ in the petioles of both species (Figure 1D). Plant part affected $\mathrm{K} \%$ in sub $(\mathrm{P}=0.002)$ and white $(\mathrm{P}=0.011)$ clover with higher $(\mathrm{P}<0.05)$ petiole concentrations of 3.3 and $4.1 \%$, respectively, than in the laminae with 1.3 and $2.2 \%$ (Figure 1B). The $0.34 \% \mathrm{P}$ in the sub clover laminae was higher $(\mathrm{P}<0.05)$ than the $0.27 \%$ in petioles (Figure 1C).

In our dataset, the full petioles represented $34 \pm 6 \%$ of sub clover and $41 \pm 6 \%$ of white clover total DW, with a range from $23 \%$ to $49 \%$ for both species.

\section{Effect of including petiole nutrient concentrations}

The change in foliar nutrient concentrations as the lamina to petiole DW ratio was changed from 100:0 (i.e. all lamina and no petiole) to a sample based on $50 \%$ lamina and $50 \%$ petiole is shown in Figure 2.

As expected, increasing the amount of petiole added
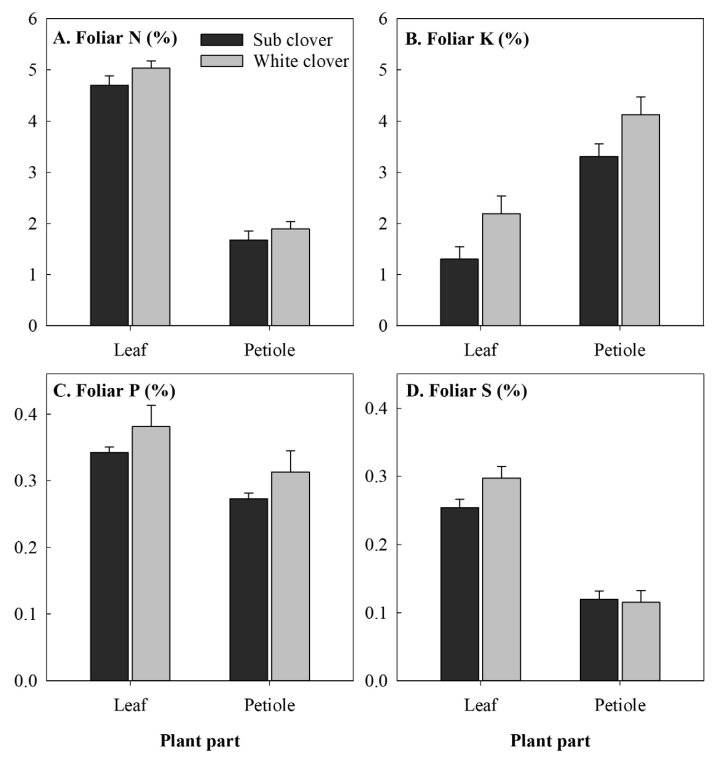

Figure 1 Nutrient concentrations (\% of DW) of lamina or petioles of A. nitrogen, B. potassium, C. phosphorus and D. sulphur in sub clover and white clover. Error bars are standard error of the mean.

to the lamina sample affected the nutrient concentration of the whole sample. The concentration of $\mathrm{N}$ declined from $5.0 \%$ with lamina only to $3.6 \%$ with a $50: 50$ lamina:petiole ratio for white clover, and from 4.7 to $3.2 \%$ for sub clover (Figure $2 \mathrm{~A}$ ). Foliar P also declined but the overall impact was not large (Figure 2C). The foliar $\mathrm{K}$ increased from 2.2 to $3.2 \%$ for white clover and 1.3 to $2.3 \%$ for the sub clover (Figure $2 \mathrm{~B}$ ). The white clover foliar S declined from 0.30 to $0.22 \%$, with increasing amounts of petiole in the sample, and from 0.25 to $0.20 \%$ for sub clover (Figure 2D).

Assuming that a 'grab sample' of white clover taken in the field has included half of the petiole ( 70:30 lamina to petiole ratio), then the resulting foliar concentrations in Figure 2 would be below the recommended critical nutrient levels for $\mathrm{N}$ and $\mathrm{S}$ compared with a lamina only sample.

The sub clover foliar nutrient levels in Figure 2, including the lamina-only samples, are all below the recommended critical nutrient levels (Table 1) reported for white clover (Cornforth \& Sinclair 1984) and, apart from N, are in the range of 'marginal deficiency' reported for sub clover by Reuter and Robinson (1997).

\section{NIR analysis}

There was no effect of species or plant part on ME (Table 5). The crude protein content of $24 \%$ in white clover was higher $(\mathrm{P}<0.05)$ than the $21 \%$ in sub clover. The differences between plant parts were more pronounced, with lamina having higher protein content 

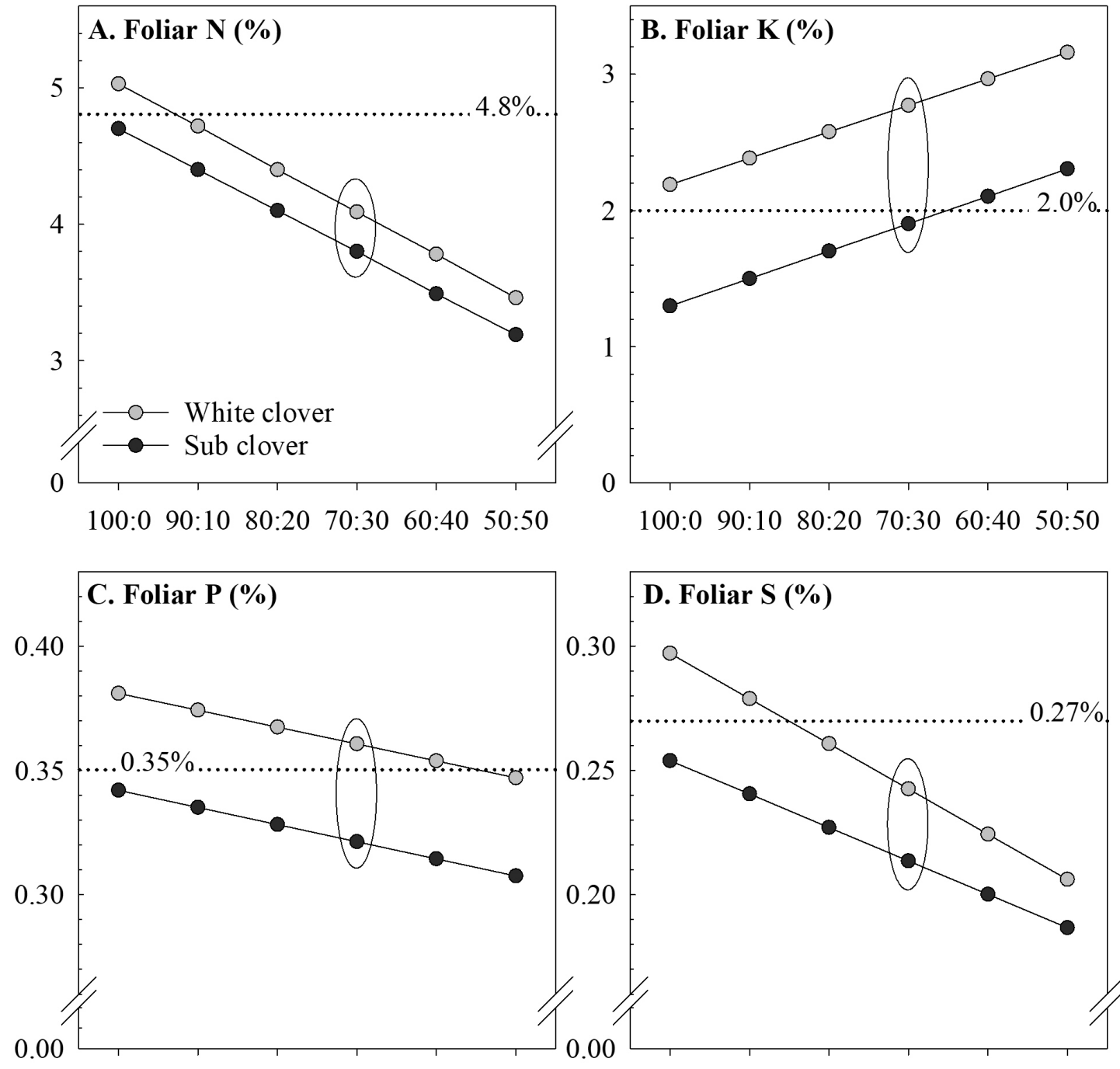

\section{Foliar S (\%)}

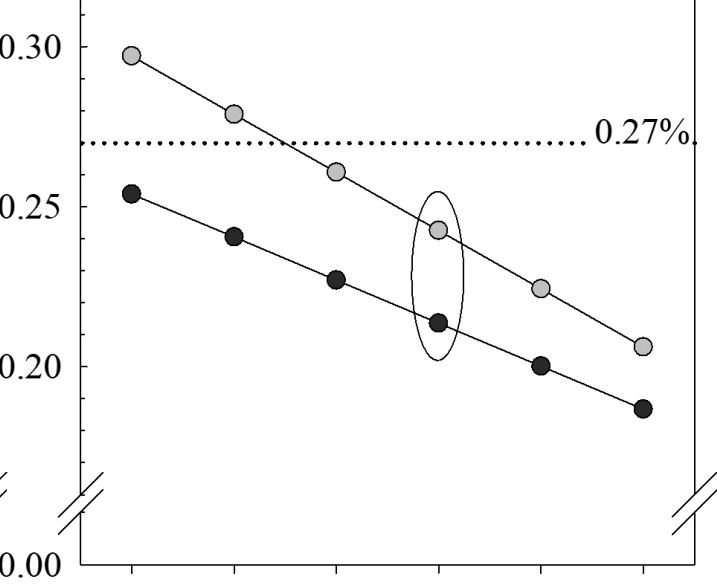

100:0 $\quad 90: 10 \quad 80: 20 \quad 70: 30 \quad 60: 40 \quad 50: 50$

100:0 90:10 80:20 $70: 30 \quad 60: 40 \quad 50: 50$

\section{Leaf to petiole DW ratio}

\section{Leaf to petiole DW ratio}

Figure 2 Changes in foliar nutrient concentrations (\%) as the proportion of petiole in the sample increases for sub and white clover A. nitrogen, B. potassium, C. phosphorous, and D. sulphur. Critical foliar nutrient values (......) for white clover from Cornforth and Sinclair (1984), see Table 1. Nutrient concentrations at a lamina to petiole ratio of 70:30 are circled, representing a 'grab sample' of clover from grazed pasture.

of $33 \%$ compared with $13 \%$ in the petiole $(\mathrm{P}<0.05)$. The ADF and NDF in petioles were higher $(\mathrm{P}<0.05)$ than in laminae (Table 5).

\section{Discussion}

Effect of clover plant part on nutrient and nutritive values

The differences found in $\mathrm{N}, \mathrm{P}, \mathrm{K}$, and $\mathrm{S}$ concentrations between laminae and petioles in sub clover and white clover (Table 4 and Figure 1) have important implications for the diagnosis of clover mineral nutrition. Including both plant structures in one sample leads to distortions in the resulting nutrient concentration values. The data shown in Figure 2 highlight the change in clover nutrient concentrations as the lamina to petiole ratio decreases. For example, the $\mathrm{N}$ status of white clover lamina alone (i.e. lamina to petiole ratio of 100:0) is 'optimum' (Cornforth \& Sinclair 1984). However, adding a small amount of petiole to the sample to give a ratio of 80:20 would 
Table 5 Metabolisable Energy (ME), crude protein, Acid Detergent Fibre (ADF) and Neutral Detergent Fibre (NFD) content of sub and white clover (WC) laminae and petioles collected from Ashley Dene and Iversen, Canterbury (see Table 2). SEM = Standard error of the mean.

\begin{tabular}{llcccc}
\hline Factor & & $\begin{array}{c}\text { ME (MJ } \\
\text { kg/DM }\end{array}$ & $\begin{array}{c}\text { Crude } \\
\text { protein\% }\end{array}$ & ADF\% & NDF\% \\
\hline Species & Sub & 11.5 & $21 \mathrm{~b}$ & 22 & 36 \\
& WC & 12.1 & $\mathbf{2 4} \mathbf{a}^{*}$ & 21 & 34 \\
\cline { 2 - 6 } & P values & 0.089 & 0.023 & 0.360 & 0.384 \\
\hline Plant part Lamina & 11.7 & $\mathbf{3 3} \mathbf{a}$ & $16 \mathrm{~b}$ & $29 \mathrm{~b}$ \\
& Petiole & 12.0 & $13 \mathrm{~b}$ & $\mathbf{2 7} \mathbf{a}$ & $\mathbf{4 0} \mathbf{a}$ \\
\cline { 2 - 6 } & P values & 0.267 & $<0.001$ & $<0.001$ & 0.005 \\
\cline { 2 - 6 } & SEM (Part) & 0.18 & 0.6 & 1.2 & 1.9 \\
\hline
\end{tabular}

* Within each factor, as in Table 4, bolded mean values were significantly greater $(P<0.05)$.

result in the $\mathrm{N} \%$ decreasing below the critical value of $4.8 \%$ (Figure 2A). From a diagnostic perspective, this gives a "false negative". The white clover lamina has adequate $\mathrm{N}$ but adding petiole into the sample would lead, in this scenario, to a misdiagnosis of $\mathrm{N}$ deficiency and possibly further unnecessary investigation into the causes of the less than 'optimal' foliar $\mathrm{N}$ concentrations.

White clover foliar S had a similar trend to foliar N. As previously noted, soil sulphate-S and organic-S at all three sites were low (Table 3 ) but foliar concentrations in the white clover laminae (100:0) would be considered optimum (per Cornforth \& Sinclair 1984). However, the $\mathrm{S}$ content declined below the critical value of $0.27 \%$ with a lamina to petiole ratio of only 80:20 (Figure 2D), which has less petiole than our lamina + full petiole sample that had a 60:40 ratio The sub clover $\mathrm{S} \%$ in the laminae was below the critical level, reported for white clover, and adding petiole would accentuate the deficiency. However, for foliar K, the reverse occurred as the inclusion of petiole, which has a higher $\mathrm{K} \%$ than lamina (Figure 1B), led to a "false positive" for sub clover (Figure 2B). In this example, the $1.3 \% \mathrm{~K}$ in the sub clover lamina is indicative of $\mathrm{K}$ deficiency but as the amount of petiole increases to a ratio of $60: 40$ the overall foliar $\mathrm{K} \%$ crosses the critical value line of $2.0 \%$ and no longer suggests that $\mathrm{K}$ fertiliser should be applied, when, in reality, it might be limiting growth.

From a clover nutritional view point, these data highlight the need to sample a single plant structure, in this case laminae only, to remove the variability that occurs from including an unknown amount of petiole. The impact of including petiole on foliar nutrient concentrations also leads to the conclusion that the majority of nutritional data published for clover species, such as sub and white, contains an inherent variability that complicates the process of: a) linking clover nutrient values to soil test values; and b) gaining a clear understanding of the impact of fertiliser applications on foliar nutrient concentrations in the lamina.

From an animal nutritive value perspective, ME did not differ between lamina and petiole but crude protein was three times higher in the lamina than the petiole (Table 5). Clover-pasture sampling for nutritive value should include the petiole because this reflects what the animal is eating and therefore the overall protein and $\mathrm{N}$ uptake by animals. Estimating herbage $\mathrm{N}$ based on the lamina alone would suggest protein levels of $30 \%$ for intake which exceeds the $18 \%$ crude protein considered optimal for animal nutrition (Waghorn et al. 2007). Thus, animal performance and nutrient leaching models should include values based on the herbage consumed, or dietary and urine-N could be grossly misrepresented. It should also be noted that livestock diets may include clover stems which also have low $\mathrm{N}$ (Ru \& Fortune 2000).

\section{Effect of clover species}

While sub clover appeared to have lower foliar nutrient concentrations than white clover (Figure 2), the difference was only significant for $\mathrm{K} \%$ (Table 4 ). The foliar nutrient ranges presented by Reuter and Robinson (1997) imply there are differences between the two species, especially for $\mathrm{N}$, although the range in values for $\mathrm{K}$ and $\mathrm{S}$ are wide and therefore not useful from a diagnostic perspective. Research is required to develop more precise values.

Further research is also required to define the foliar nutrition of sub and white clover laminae based on the lifecycle differences between perennial white clover and annual sub clover and the different environments where they are grown in New Zealand. Such research should include a focus on accompanying soil nutrient data, identifying the optimum time during the growing season to take samples, and the logistics of collecting and preparing lamina samples for analysis.

\section{Proposed clover sampling method}

Nutritional work involving clover in pot experiments and from the field should focus on sampling laminae only as this is a simple morphological feature to both identify and sample. Sampling one plant 'structure' (i.e. laminae alone) and developing critical nutrient levels for these will remove the distortions that arise when variable proportions of petiole and/or stem are included in samples for chemical analyses.

Reuter and Robinson (1997) recommended sampling the youngest open leaf blades before clovers flower but this appears impractical when sampling regrowth 
from a pasture. We believe valid samples of pasture herbage, which contain mature clover laminae, can be collected in the field by following standard advice such as avoiding urine and dung patches. Damaged and obviously older laminae can be rejected, together with petioles of selected younger laminae, during sorting of a well-mixed bulk sample. The additional time required to select laminae from the field sample will remove a major source of error from current practices and improve the integrity of the data.

The ideal time for sampling annual clovers such as sub is early spring before flowering (Reuter \& Robinson 1997). Ru and Fortune (2000) found that sub clover lamina $\mathrm{N}$ declined from the start of flowering. Sub clover laminae sampled from Omarama in December, when plants were going into senescence, contained $2.5 \% \mathrm{~N}$ (R.J. Lucas, unpublished data). Generally advice for sampling white clover specifies periods when growth is active (Cornforth \& Sinclair 1984) but preferably before flowering (Weir \& Cresswell 1994).

The results of this study suggest current critical foliar nutrient values used for diagnosing white clover nutrition are not appropriate for sub clover and possibly not for other species of clover. Separate foliar nutrient critical values are required especially for sub clover which is an economically important legume in New Zealand dryland farming systems. The 'marginal deficiency' ranges described by Reuter and Robinson (1997) for sub clover are too broad and need to be revised.

Separate pasture samples are required for determining animal feed nutritive value and such samples need to include clover petioles, and grass and herb components, to represent grazing intake by livestock.

Further research is required to build a dataset of sub clover and white clover lamina nutrient concentrations from samples collected during the growing season to identify the optimum time to take samples, develop specific foliar nutrient criteria, and investigate the relationship with soil nutrient data.

\section{Conclusions/Practical implications/Relevance}

Data from analyses of samples that aim to provide data on the energy and mineral content of animal diets should not be used to determine fertiliser requirements of the legume component of grazed pastures.

Lamina-only samples from the dominant clover in a grazed pasture will provide more reliable data for diagnosing mineral nutrition requirements than samples that contain variable amounts of petiole. Samples that contain petioles may underestimate $\mathrm{N}, \mathrm{S}$, and $\mathrm{P}$ values and exaggerate $\mathrm{K}$ content.

New nutrient standards based on lamina-only samples should be developed for important pasture legumes such as white and sub clovers. These standards will recognise differences between species so that fertiliser recommendations ensure $\mathrm{N}$ fixation is not inhibited by nutrient deficiencies.

\section{ACKNOWLEDGEMENTS}

Lincoln University staff Malcolm Smith (organising sample grinding), Lynne Clucas and Vicky Zhang (chemical analysis of samples), and Shuang Jiang (assistance with NIR analysis). Dan and Reidun Nicholson, owners of Tokaroa Farm, Wairarapa. This work was funded by the SFF Project 408090 "Sub 4 Spring”, Beef + Lamb New Zealand, Luisetti Seeds and Seed Force ${ }^{\mathrm{TM}}$ Ltd and "Regenerating Hill Country Pastures" funded by Beef + Lamb New Zealand. Mr Roland Stead also provided financial assistance.

\section{REFERENCES}

Cornforth IS, Sinclair AG. 1984. Fertiliser and Lime Recommendations for Pastures and Crops in New Zealand. 2nd ed. Agricultural Research Division, Ministry of Agriculture \& Fisheries, New Zealand, $76 \mathrm{p}$.

Costello T, Costello A. 2003. Subterranean clover in North Canterbury sheep pastures. Presented at: Legumes for dryland pastures: proceedings of a New Zealand Grassland Association (Inc.) Symposium. Lincoln University. Pp. 189-192.

Cox JE. 1978. Soils and agriculture of part Paparua County, Canterbury, New Zealand. New Zealand Soil Bureau Bulletin 34. DSIR, Wellington.

Edmeades DC, Thorrold BS, Roberts AHC. 2005. The diagnosis and correction of sulphur deficiency and the management of sulphur requirements in New Zealand pastures: a review. Australian Journal of Experimental Agriculture 45: 1205-1223.

Gillingham AG, Gray MH, Smith DR. 1998. Pasture responses to phosphorus and nitrogen fertilisers on dry hill country. Proceedings of the New Zealand Grassland Association 60: 135-140.

Grigg DW, Grigg JM, Lucas RJ. 2008. Maximising subterranean clover in Marlborough's hill country is key to weaning $80 \%$ of sale lambs prime. Proceedings of the New Zealand Grassland Association 70: 25-29.

Hewitt AE. 2010. New Zealand Soil Classification 4th edition. Manaaki Whenua-Landcare Research New Zealand Limited, New Zealand.

Maxwell TMR, Moir JL, Edwards GR. 2012. Sulphur and lime response of four adventive annual clovers grown in a New Zealand high country soil under glasshouse conditions. New Zealand Journal of Agricultural Research 55: 47-62.

Maxwell TMR, Moir JL, Edwards GR. 2013. Phosphorus response and efficiency of four adventive annual clovers grown in a New Zealand high country soil under glasshouse conditions. New Zealand 
Journal of Agricultural Research 56: 203-214.

McNaught KJ. 1958. Potassium deficiency in pastures

1. potassium content of legumes and grasses. New Zealand Journal of Agricultural Research 1: 148181.

McNaught KJ. 1970. Diagnosis of mineral deficiencies in grass-legume pastures by plant analysis. Presented at: Proceedings of the XI International Grassland Congress. Surfers Paradise. Pp. 334-338.

Moir J, Jordan J, Moot D, Lucas R. 2016. Phosphorous response and optimum $\mathrm{pH}$ values of twelve legumes grown in an acid upland New Zealand soil under glasshouse conditions. Journal of Soil Science and Plant Nutrition 16: 438-460.

Morton JD, Smith LC. 2000. Chemical analysis of pasture for measuring nutrient status and requirements. In: Currie LD, Loganathan P Eds. Soil research a knowledge industry for land-based exports, pp. 147-156. Occasional report No. 13. Fertiliser and Lime Research Centre, Massey University, Palmerston North, New Zealand.

Morton JD, Roberts AHC. 2018. Fertiliser use on New Zealand sheep and beef farms. Fertiliser Association of New Zealand. Wellington, New Zealand, 52 p. Retrieved 12 March 2019 from https://beeflambnz. com/knowledge-hub/PDF/fertiliser-use-newzealand-sheep-and-beef-farms

Olykan ST, Lucas RJ, Nicholson DJ, Doscher C, Moot DJ. 2019. Maximising the subterranean clover content on a summer-dry Wairarapa hill-country farm through grazing management. Journal of New Zealand Grasslands 81: 91-100.

Osborne BG, Fearn T, Hindle PH. 1993. Practical NIR Spectroscopy: with applications in food and beverage analysis. Longman Scientific and Technical, Essex, UK.

Reuter DJ, Robinson JB. 1997. Plant analysis - an interpretation manual. 2 ed. CSIRO Publishing, Victoria, Australia.

$\mathrm{Ru}$ YJ, Fortune JA. 1999. Effect of grazing intensity and cultivar on morphology, phenology, and nutritive value of subterranean clover I. Morphology and phenology of subterranean clover during the growing season. Australian Journal of Agricultural Research 50: 1191-1201.

$\mathrm{Ru}$ YJ, Fortune JA. 2000. Variation in nutritive value of plant parts of subterranean clover (Trifolium subterraneum L.). Australian Journal of Experimental Agriculture 40: 397-403.

S-MAP. 2018. Retrieved 13 December 2018 from https://smap.landcareresearch.co.nz

Waghorn GC, Burke JL, Kolver ES. 2007. Principles of feeding value. In: Rattray PV, Brookes IM, Nicol AM Eds. Pasture supplements for grazing animals, pp. 35-59. New Zealand Society of Animal Production. Occasional Publication No. 14.

Weir RG, Cresswell GC. 1994. Plant nutrient disorders 4: Pastures and field crops. Inkata Press, Melbourne. 